 \\ Enhancing photovoltaic performance of perovskite solar cells utilizing \\ germanium nanoparticles \\ Zhang, Chenxi; Li, Zaifeng; Deng, Xueshuang; Yan, Bing; Wang, Zengbo; \\ Chen, Xiaohong; Sun, Zhuo; Huang, Sumei

\section{Solar Energy} \\ DOI: \\ 10.1016/j.solener.2019.06.069 \\ Published: 01/08/2019
}

Peer reviewed version

Cyswllt i'r cyhoeddiad / Link to publication

Dyfyniad o'r fersiwn a gyhoeddwyd / Citation for published version (APA):

Zhang, C., Li, Z., Deng, X., Yan, B., Wang, Z., Chen, X., Sun, Z., \& Huang, S. (2019). Enhancing photovoltaic performance of perovskite solar cells utilizing germanium nanoparticles. Solar Energy, 188, 839-848. https://doi.org/10.1016/j.solener.2019.06.069

\footnotetext{
Hawliau Cyffredinol / General rights

Copyright and moral rights for the publications made accessible in the public portal are retained by the authors and/or other copyright owners and it is a condition of accessing publications that users recognise and abide by the legal requirements associated with these rights.

- Users may download and print one copy of any publication from the public portal for the purpose of private study or research.

- You may not further distribute the material or use it for any profit-making activity or commercial gain

- You may freely distribute the URL identifying the publication in the public portal ?
}

Take down policy

If you believe that this document breaches copyright please contact us providing details, and we will remove access to the work immediately and investigate your claim. 


\title{
Enhancing photovoltaic performance of perovskite solar cells utilizing germanium nanoparticles
}

\author{
Chenxi Zhang ${ }^{\mathrm{a}}$, Zaifeng $\mathrm{Li}^{\mathrm{b}}$, Xueshuang Deng ${ }^{\mathrm{a}}$, Bing Yan ${ }^{\mathrm{c}}$, Zengbo Wang ${ }^{\mathrm{c}}$, Xiaohong Chen $^{\mathrm{a}}$, \\ Zhuo Sun ${ }^{\mathrm{a}}$, Sumei Huang, \\ ${ }^{a}$ Engineering Research Center for Nanophotonics \& Advanced Instrument, Ministry of Education, School of Physics and Materials Science, East China Normal University, \\ North Zhongshan Rd. 3663, Shanghai 200062, PR China \\ ${ }^{\mathrm{b}}$ College of Civil Engineering, Tongji University, Siping Road 1239, Shanghai 200092, PR China \\ ${ }^{\mathrm{c}}$ School of Electronic Engineering, Bangor University, Bangor LL57 1UT, UK
}

\section{A R T I C L E I N F O}

\section{Keywords:}

Organometal halide perovskite

Solar cells

Crystallinity

Germanium nanoparticle

Mie scattering

\begin{abstract}
A B S T R A C T
Morphological and crystalline control over hybrid organic-inorganic perovskite films is pivotal for efficient photovoltaic (PV) performance devices. Yet, this remains very challenging for solution processed perovskite solar cells (PVSCs), especially mesoscopic PVSCs, due to the complicated crystallization kinetics of hybrid semiconductor materials within dynamic spin-coating and post annealing. In this work, colloidal Ge nanoparticles (NPs) were added onto a mesoporous $\mathrm{TiO}_{2}\left(\mathrm{~m}-\mathrm{TiO}_{2}\right)$ electron transporting layer (ETL) to regulate perovskite crystal growth. Systematic investigation and optimization disclose that incorporation of an appropriate ratio of $\mathrm{Ge}$ NPs onto the $\mathrm{m}-\mathrm{TiO}_{2} \mathrm{ETL}$ can simultaneously increase the size of the $\mathrm{CH}_{3} \mathrm{NH}_{3} \mathrm{PbI}_{3} \mathrm{crystals}$, decrease the number of the grain boundaries and promote the interfacial properties of perovskite/m- $\mathrm{TiO}$. The related mechanisms are clarified through detailed morphology and crystal structure analyses. The electron mobility of the perovskite absorber, determined using the space charge limited current (SCLC) method, was increased by over 5 times when an optimized amount of Ge NPs were employed. Average power conversion efficiency (PCE) of $18.59 \%$ was achieved from 16 cells and the best PCE of $19.6 \%$ was attained via the addition of the optimized amount of Ge NPs. We study the fundamentals of optics and physics behind the PVSC device based on the high refractive index Ge NPs. This work offers an innovative scenario to enhance the performance of perovskite based optoelectronics by employing optically stable, chemically inert, low-cost and green semiconductor NPs.
\end{abstract}

\section{Introduction}

Perovskite-structured organometal halide solar cells were first introduced by Miyasakaet al. in 2009, and since then this photovoltaic (PV) technology has attracted tremendous attention, exhibiting an expeditious rise in the power conversion efficiency (PCE) from $3.8 \%$ to presently certified $24.2 \%$ (Akihiro et al., 2009; Lee et al., 2012; Nam Joong et al., 2015; Green et al., 2018; https://www.nrel.gov/pv/assets/ pdfs/best-research-cell-efficiencies-190416.pdf). Such rapid and stunning progresses have been made primarily through consecutive investigations on the morphology control of hybrid perovskite films; optimization of the perovskite composition, innovative device configuration as well as interface engineering of perovskite solar cells (PVSCs) (Wang et al., 2018b; Zeng et al., 2017; Zhou et al., 2019; Zhang et al., 2018; Wang et al., 2018a; Lei et al., 2018; Nam Joong et al., 2014;
Zhang et al., 2016; Po-Wei et al., 2014; Zhang et al., 2019; Zhang et al., 2017b; Bi et al., 2018; Pellet et al., 2014; Saliba et al., 2016a; TurrenCruz et al., 2018; Aharon et al., 2015; Bi et al., 2017). Special attention has been paid to various morphology engineering technologies, including solvent engineering (Nam Joong et al., 2014; Zhang et al., 2016); additives engineering using different chemicals as ingredients or ligands (Po-Wei et al., 2014; Zhang et al., 2019; Zhang et al., 2017b; Bi et al., 2018); compositional engineering (Pellet et al., 2014; Saliba et al., 2016a; Turren-Cruz et al., 2018) and thermal engineering (Aharon et al., 2015; Bi et al., 2017). Moreover; interface engineering has been considerably studied by managing the carrier dynamics at the interfaces and designing a rational structure to improve the performance and stability of the devices (Zhou et al., 2014; Noel et al., 2014). The proper modification of the interface between the perovskite film and the electron transporting layer (ETL) or the hole transporting layer

\footnotetext{
* Corresponding author.

E-mail address: smhuang@phy.ecnu.edu.cn (S. Huang).
} 
HTL can achieve efficient, stable, and hysteresis-less PVSCs (Saliba et al., 2016b; Tavakoli et al., 2018). Among all the studies of PVSCs, the enhancement of surface morphology of hybrid perovskite films has become the key issue and nowadays draws the most attention. Moreover, in rationally designed and assembled PV devices, though perovskite absorbers can efficiently employ visible light, further improvements for PVSC devices are sharply needed in order to compete with the other PV technologies, such as silicon, GaAs, CIGS and CdTe solar cells, (Green et al., 2018; Shi et al., 2015; Zhu et al., 2011; https:// www.nrel.gov/pv/assets/pdfs/best-research-cell-efficiencies-190416. pdf) and fully realize their potential as PV solar cells. For instance, leading edge crystalline silicon PV devices have demonstrated a remarkable progress in the last several years, with an efficiency up to 26.6\% (Green et al., 2018; https://www.nrel.gov/pv/assets/pdfs/bestresearch-cell-efficiencies-190416.pdf). Consequently, further advancements in the PV performance of PVSC technology are required to close the gap in PCEs with the Si PVs.

One tactic to revolutionize the PCE of PVSCs for the maximum accomplishable performance is to optically engineer the device to maximize light coupling/trapping into the photoactive layer. For this purpose, plasmonic solar cells have been recently proposed and developed to achieve nearly complete light absorption with less thickness for more efficient carrier collection (Carreteropalacios et al., 2016; Kakavelakis et al., 2017). Several groups have reported the incorporation of resonant colloidal metallic nanoparticls (NPs) in the scaffold layer of mesoporous perovskite solar cells (Zhang et al., 2013; Saliba et al., 2015; Cheng et al., 2017; Luo et al., 2017) or in the compact ETL of PVSCs (Yuan et al., 2015). By using nanostructured Au, Ag and Au-Ag, the average PCE was enhanced from $0.6 \%$ (Lee et al., 2016) to $44 \%$ (Luo et al., 2017). The incorporation of plasmonic metallic nanostructures into PVSCs not only impacts the light absorption by the device, but also positively or negatively affects their electrical properties, and the overall efficiency of the plasmonic PVSCs can be increased through various mechanisms. However, there are several limitations to the use of metallic nanostructures, including their chemical and physical stability, charge recombination, large optical losses at shorter wavelengths in the visible and UV ranges due to the interband electronic transitions of precious metals, and high cost and scarce supply of usually used noble metals (Jang et al., 2016; Domanski et al., 2016).

Recently, optically resonant dielectric and semiconductor nanostructures, especially with a high value of the refractive index, appear to provide a comparable, or even better improvement in thin-film solar cells and other optoelectronic devices (Akimov et al., 2010; Jahani and Jacob, 2016; Kuznetsov et al., 2016; Bontempi et al., 2017). Comparing to metallic plasmonic nanostructures, these nanomaterials are likely to be superior in low dissipation in the visible wavelength, ultralow lightinto-heat conversion (Caldarola et al., 2015); the excitation of both electric and magnetic resonances (Kuznetsov et al., 2012), low cost, high chemical stability and temperature resistance. Owing to these advantages, GaAs, Si and Ge nanoparticles can supply a viable and better alternative to noble metal nanostructures for photovoltaics applications.

In this work, for the first time to our knowledge, Ge NPs are applied to improve the PV performance of PVSCs. Colloidal Ge NPs were incorporated between porous $\mathrm{TiO}_{2}$ and perovskite semiconductor layers. The effects of Ge nanostructures on the PV performance of PVSCs were systematically investigated. The microstructures of Ge NPs modified porous $\mathrm{TiO}_{2}$ and perovskite films, defect densities and charge transportation properties of the perovskite absorber and its interface with $\mathrm{TiO}_{2}$ were evaluated using a space charge limited current (SCLC) method, Electrochemical impedance spectroscopy (EIS) and time-resolved and steady-state photoluminescence (PL). The addition of Ge NPs with an optimized concentration simultaneously improved the crystallinity and morphology of the perovskite film and the $\mathrm{TiO}_{2}-$ perovskite interfacial properties, thereby promoting the short-circuit current density and the fill factor. Consequently, efficient Ge NPs based perovskite devices were obtained with average power conversion efficiency (PCE) of $18.59 \%$, demonstrating over 14\% enhancement, compared with the reference device without Ge NPs. The related PV performance enhancement mechanisms behind the PVSC device based on the high refractive index Ge nanoparticles were discussed.

\section{Experimental}

\subsection{Chemicals}

All materials were bought from either Alfa Aesar or Sigma-Aldrich, unless specified, and employed without further purification. $\mathrm{CH}_{3} \mathrm{NH}_{3} \mathrm{I}$ was synthesized according to a previous study (Im et al., 2011). Ge NPs was purchased from Guangzhou HongWu material Technology Co., ltd.

\subsection{Fabrication of solar cells}

FTO-coated glass, compact $\mathrm{TiO}_{2}\left(\mathrm{c}-\mathrm{TiO}_{2}\right)$ and mesoporous $\mathrm{TiO}_{2}(\mathrm{~m}$ $\mathrm{TiO}_{2}$ ) layers were prepared according to the procedures reported in our previous work (Luo et al., 2018). Colloidal Ge NPs were homogeneously dispersed in ethanol at different concentrations. The diameter of the $\mathrm{Ge}$ $\mathrm{NPs}$ is about $100 \mathrm{~nm}$. After the mesoporous $\mathrm{TiO}_{2}$ film sample was cooled down to room temperature; $100 \mu \mathrm{L}$ of Ge NP solution $(0.2$ to $1.0 \mathrm{mg} \mathrm{mL}^{-1}$ ) was spin-coated onto the mesoporous film surface, and then, the sample was heated at $100{ }^{\circ} \mathrm{C}$ for $30 \mathrm{~min}$ on a hotplate in air. The perovskite layers were prepared by a one-step process using a homogeneous mixture of dimethylformamide (DMF), dimethylsulphoxide (DMSO), $\mathrm{PbI}_{2}$ and $\mathrm{CH}_{3} \mathrm{NH}_{3}$ I. In brief, $578.5 \mathrm{mg}$ of $\mathrm{PbI}_{2}$ and $197.5 \mathrm{mg}$ of $\mathrm{CH}_{3} \mathrm{NH}_{3} \mathrm{I}$ were blended in $200 \mu \mathrm{L}$ of DMSO and $800 \mu \mathrm{L}$ of $\mathrm{DMF}$ at the temperature of $60^{\circ} \mathrm{C}$ with stirring for $12 \mathrm{~h}$. The fully dissolved and well-distributed perovskite precursor solution was spincoated on the Ge NP coated $\mathrm{m}-\mathrm{TiO}_{2}$ layers at $4000 \mathrm{rpm}$ for $20 \mathrm{~s}$, and $0.5 \mathrm{~mL}$ of diethyl ether was slowly dripped on the rotating sample before the sample surface changed to be a turbid appearance due to the speedy vaporization of DMF. $72.3 \mathrm{mg}$ of Spiro-OMeTAD, $28.8 \mu \mathrm{L}$ of 4tert-butyl pyridine (TBP) and $17.5 \mu \mathrm{L}$ of bis(trifluoromethylsulfonyl) imide lithium salt (Li-TFSI) in acetonitrile $\left(520 \mathrm{mg} \mathrm{mL}^{-1}\right)$ were dissolved in $1 \mathrm{~mL}$ chlorobenzene to obtain a clear yellowish spiroMeOTAD solution. After the perovskite film samples were cooled down to room temperature, the formed spiro-MeOTAD solutions were spincoated onto the perovskite films at $4000 \mathrm{rpm}$ for $50 \mathrm{~s}$. To finalize the fabrication of PVSC solar cells, a $100 \mathrm{~nm}$ thick $\mathrm{AgAl}$ alloy electrode was further thermally evaporated onto the HTL films to form the back contact of the device.

\subsection{Characterization}

The morphology, structure and composition of samples were examined and characterized by field-emission scanning electron microscopy (FESEM, Hitachi S-4800) and X-ray diffraction (XRD, Holland Panalytical PRO PW3040/60) with $\mathrm{Cu}$ Ka radiation $(\mathrm{V}=30 \mathrm{kV}$, $\mathrm{I}=25 \mathrm{~mA}$ ). The optical absorption spectra of the perovskite layers were measured by UV-Vis-NIR light absorption spectroscopy (Lambda 950, PerkinElmer). Photoluminescence (PL) spectra were characterized at room temperature using a HORIBA Jobin Yvon fluoromax-4 fluorescence spectrophotometer with an excitation wavelength of $507 \mathrm{~nm}$. The time-resolved PL (TRPL) spectra were measured by a picosecond timecorrelated single-photon counting (TCSPC) equipment. The meticulous information about this picosecond TCSPC equipment is described in the ref. (Liu et al., 2014). The photocurrent density-voltage $(J$ - $V$ ) curves were recorded by a Keithley model 2440 Source Meter under irradiation of simulated AM $1.5 \mathrm{G}$ solar light from a Newport solar simulator system. The system is equipped with a $1 \mathrm{~kW}$ Xenon arc lamp (Oriel) and was calibrated with a standard Si reference cell. A metallic mask with an aperture of about $0.09 \mathrm{~cm}^{2}$ was applied during the $\mathrm{PV}$ performance characterization. External quantum efficiency (EQE) (74125, Oriel, 


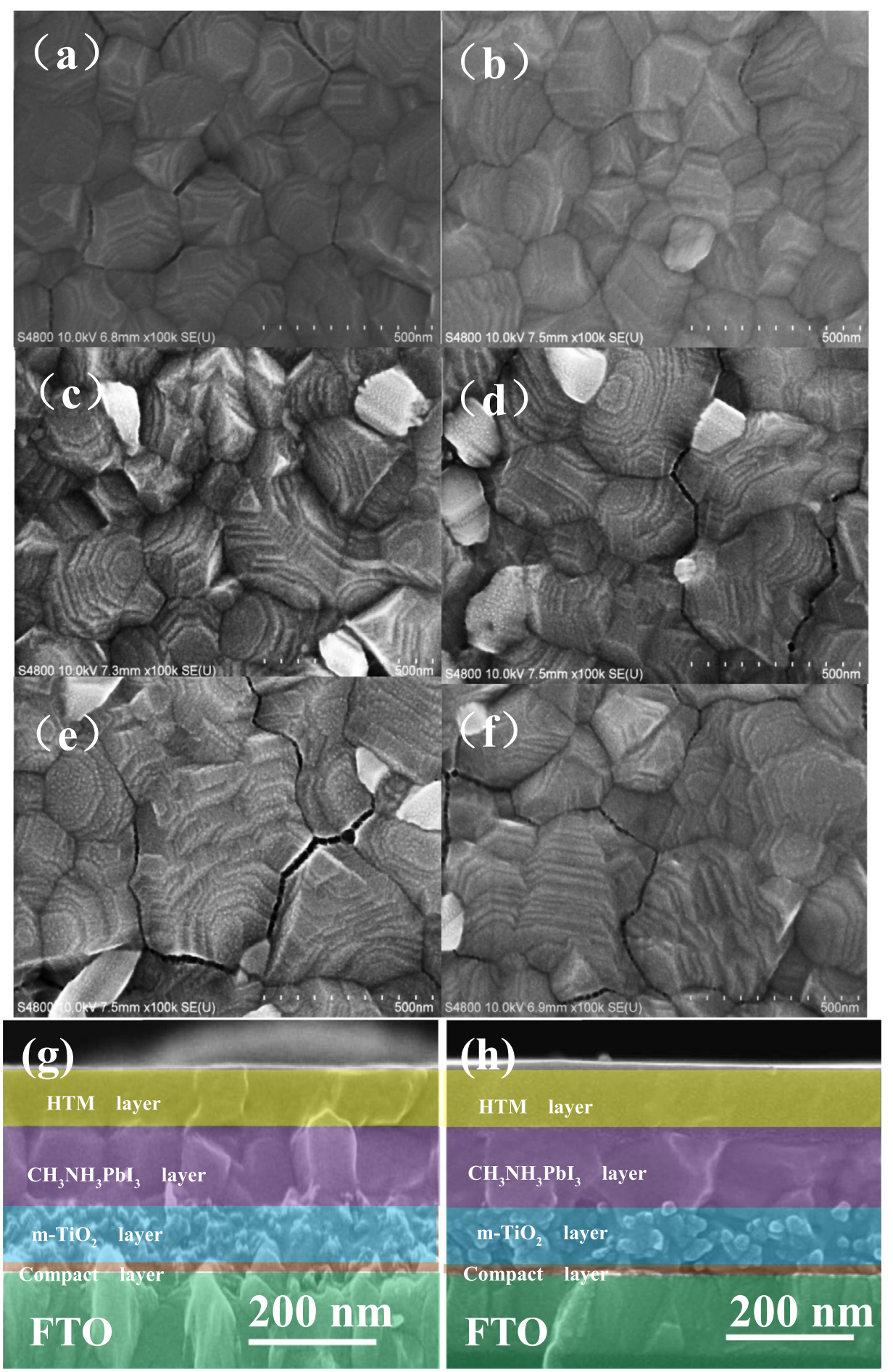

Fig. 1. Top-view FESEM images (a-f) of perovskite layers on the $\mathrm{m}-\mathrm{TiO}_{2}$ modified with different concentrations of Ge NP solution $(0,0.2,0.4,0.6,0.8$ and $1.0 \mathrm{mg} \mathrm{mL}^{-1}$ ). Cross-sectional FESEM images of perovskite layers on $\mathrm{m}-\mathrm{TiO}_{2}(\mathrm{~g})$ without modification and $(\mathrm{h})$ with modification using a Ge NP solution concentration of $0.4 \mathrm{mg} \mathrm{mL}^{-1}$.

USA) was measured for PVSCs.

\section{Results and discussion}

The effect of the addition of Ge NPs on the morphology of the provskite layers was examined by scanning electron microscopy. Fig. 1 shows the top-view and cross-sectional SEM images of the perovskite films on mesoporous $\mathrm{TiO}_{2}$ modified with different $\mathrm{Ge}$ NP concentrations of 0 (control), $0.2,0.4,0.6,0.8$ and $1.0 \mathrm{mg} \mathrm{mL}^{-1}$. As can be seen in
Fig. 1(a)-(f), for all the used Ge NP concentrations, perovskite crystals are closely interconnected to form a uniform, highly crystalline, and high coverage perovskite layer on the top of the $\mathrm{m}-\mathrm{TiO}_{2}$, which is necessary for the fabrication of efficient solar cell devices. It should be noted the obvious cracks in the perovskite film were formed during SEM imaging due to the impact of accelerated electrons at a high acceleration voltage of $10 \mathrm{kV}$. The formation of the cracks on the surface of the perovskite samples was visible to the naked eyes during the SEM analysis and characterization. The top-view SEM images shown in Fig. 1 
disclose that the perovskite grain is about $200 \mathrm{~nm}$ in the films without Ge NP modification or modified with a low Ge NP concentration of $0.2 \mathrm{mg} \mathrm{mL}^{-1}$. In contrast, the perovskite crystal remarkably increases when the Ge NP concentration is further increased from $0.2 \mathrm{mg} \mathrm{mL}^{-1}$, and the crystallite size even exceeds $1.0 \mu \mathrm{m}$ at a Ge NP solution concentration of $1.0 \mathrm{mg} \mathrm{mL}^{-1}$. The continuous increase of the perovskite crystal size with the Ge NP concentration from 0 to $1.0 \mathrm{mg} \mathrm{mL}^{-1}$ is more clearly presented in the low magnification FESEM images and their grain size distributions shown in Figs. S1 and S2.

Fig. $1(\mathrm{~g})$ and $(\mathrm{h})$ present the corresponding cross-section SEM images of the perovskite films without modification and with modification using a Ge NP concentration of $0.4 \mathrm{mg} \mathrm{mL}^{-1}$, respectively. From the cross-section SEM analysis, the control perovskite absorber without Ge NP modification is consisted of crystals with a wide transverse size distribution (100-150 nm) in the capping layer, which produces rough and irregular cross-section morphologies. With the modification of $0.4 \mathrm{mg} \mathrm{mL}^{-1} \mathrm{Ge}$ NPs, the cross-section morphological characteristics of the perovskite absorber is much more condensed and homogeneous, where typical crystal transverse sizes in the capping layer are with a much narrower size distribution $(180-200 \mathrm{~nm})$. Fewer grain boundaries are visible within the plane of the capping layer, proposing lower density of defects. This is anticipated to decrease the non-radiative charge carrier recombination driven by defects, promoting the open circuit voltage $\left(\mathrm{V}_{\mathrm{OC}}\right)$ of the PVSC devices (Bi et al., 2016).

XRD studies were performed to examine the crystalline transformation of the perovskite with the addition Ge NPs onto the $\mathrm{m}-\mathrm{TiO}_{2}$. Diffractograms of all the $\mathrm{CH}_{3} \mathrm{NH}_{3} \mathrm{PbI}_{3}$ samples show characteristic peaks at $15.44^{\circ}, 29.78^{\circ}, 33.20^{\circ}, 41.90^{\circ}, 44.48^{\circ}$, which can be indexed to the reflections from (1 10 ), (2 20 ), (3 10 ), (2 24 ), and (3 14 ) crystal planes, respectively, signifying a tetragonal perovskite $\mathrm{CH}_{3} \mathrm{NH}_{3} \mathrm{PbI}_{3}$ phase. The intensities of XRD peaks from both ( 1110$)$ and $\left(\begin{array}{lll}2 & 2 & 0\end{array}\right)$ planes for the perovskite films modified with Ge NPs is considerably heightened, as compared to that of the control $\mathrm{CH}_{3} \mathrm{NH}_{3} \mathrm{PbI}_{3}$ film without $\mathrm{Ge}$ NP modification, exhibiting a higher degree of crystallinity. And it should be underlined that the $(220)$ XRD peak intensity of the perovskite absorber formed with a Ge NP content greater than $0.2 \mathrm{mg} \mathrm{mL}^{-1}$ is almost twice as high as that of the control perovskite film, revealing the prominent effect of Ge NPs on facilitating the perovskite crystals growing along the preferential orientation towards the

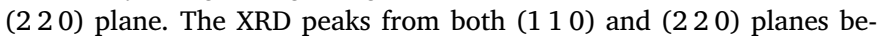
came more and more intense with the increase of the Ge NP concentration from $0.2 \mathrm{mg} \mathrm{mL}^{-1}$ to $1.0 \mathrm{mg} \mathrm{mL}^{-1}$. The result is well agreed with disappearance of the small grains and better morphologies in the provskite film with the increase of Ge NP content shown in Figs. 1, S1 and S2.

From the above SEM and XRD measurement results, it is noted that the addition of Ge NPs onto $\mathrm{m}-\mathrm{TiO}_{2}$ can simultaneously increase the crystallinity and the grain size as well as improve the morphology of the perovskite film. We rationalize this effect in terms of the hydrophobic nature of Ge NP-mesoporous $\mathrm{TiO}_{2}$ surface because the hydrophobicity influences the nucleation and grain growth behavior of perovskite semiconductors. In our work, the perovskite films were fabricated using one-step spin-coating approach. In this processing method, $\mathrm{PbI}_{2}$ and $\mathrm{CH}_{3} \mathrm{NH}_{3} \mathrm{PbI}_{3}$ were blended together in the mixed solvent of DMF and DMSO. The perovskite precursor films were spin-coated on mesoporous $\mathrm{TiO}_{2}$ modified with different amounts of Ge NPs, and a subsequent heat treatment was performed for the formation of $\mathrm{CH}_{3} \mathrm{NH}_{3} \mathrm{PbI}_{3}$ absorbers. Figs. 3(a), (b) and S4 (a)-(d) show the contact angle of water on $\mathrm{m}-\mathrm{TiO}_{2}$ modified with different Ge NP concentrations of 0 (control), 0.2, 0.4, $0.6,0.8$ and $1.0 \mathrm{mg} \mathrm{mL}^{-1}$. With the increase of Ge NP concentration, more Ge NPs were deposited on the $\mathrm{m}-\mathrm{TiO}_{2}$ film as shown in Fig. S5. It was also found that incorporation of Ge NPs decreased the wetting capability of the $\mathrm{m}-\mathrm{TiO}_{2}$ electrode surface to water, compared to the case of the bare $\mathrm{m}-\mathrm{TiO}_{2}$ without Ge NPs. And the contacting angle increased with the increase of the content of Ge NPs. Specifically, the contacting angles of water on the bare $\mathrm{m}-\mathrm{TiO}_{2}$ electrode and the modified $\mathrm{m}-\mathrm{TiO}_{2}$ film with a Ge NP content of $0.4 \mathrm{mg} \mathrm{mL}^{-1}$ are $6.14^{\circ}$ and $16.26^{\circ}$, as shown in Fig. 3(a) and (b), respectively. The obtained contacting angle value symbolizes the wetting ability of the $\mathrm{TiO}_{2}$ electrode surface to water. In addition, the collected contacting angle data could also represent the wetting capability of these $\mathrm{TiO}_{2}$ electrode surfaces to solid-state $\mathrm{CH}_{3} \mathrm{NH}_{3} \mathrm{PbI}_{3}$ (Bi et al., 2015; Miao et al., 2016). The formation of highly crystalline and large grains on Ge NP modified $\mathrm{m}-\mathrm{TiO}_{2}$ ETLs can be associated with the hydrophobic attribute of the $\mathrm{m}$ $\mathrm{TiO}_{2}$ surface after Ge NP modification. In our one-step solution processing method for the absorber; the first step of perovskite film formation was perovskite nucleation on the $\mathrm{m}-\mathrm{TiO}_{2}$ electrode after the chemical reaction of $\mathrm{CH}_{3} \mathrm{NH}_{3} \mathrm{PbI}_{3}$ and $\mathrm{PbI}_{2}$. For the bare m-TiO 2 electrode, a small contacting angle of $6.14^{\circ}$ induced a very small Gibbs free energy barrier for nucleation, which greatly boosted the nucleation and produced very dense nuclei on the wetting surface of the bare $\mathrm{m}-\mathrm{TiO}_{2}$. The addition of Ge NPs onto the $\mathrm{m}-\mathrm{TiO}_{2}$ ETL made the ETL less hydrophilic for the perovskite precursor. The greater the contacting angle with the increase of the Ge NP content, the closer to the nonwetted surface state, which more significantly decreased the surface tension dragging force on the perovskite layer and prevented the formation of too dense nuclei, resulting in a higher grain boundary mobility and thus allows larger grains to grow, as shown in Fig. 3(c). The XRD and SEM measurement results from the $\mathrm{CH}_{3} \mathrm{NH}_{3} \mathrm{PbI}_{3}$ films on the $\mathrm{m}-\mathrm{TiO}_{2}$ ETLs modified with different amounts of Ge NPs, as shown in Figs. 1 and 2, clearly confirm the formation mechanism shown in Fig. 3(c). The average grain size is obviously larger for $\mathrm{CH}_{3} \mathrm{NH}_{3} \mathrm{PbI}_{3}$ films on the higher hydrophobic Ge NP-ETLs with the higher Ge NP content. Specially, when the Ge NP content is $\geq 0.4 \mathrm{mg} \mathrm{mL}^{-1}$, most of grains in $\mathrm{CH}_{3} \mathrm{NH}_{3} \mathrm{PbI}_{3}$ films on Ge coated $\mathrm{m}-\mathrm{TiO}_{2}$ layer were much larger than the thickness of the perovskite capping layers.

Fig. 4(a) displays UV-Vis absorption spectra of $\mathrm{m}-\mathrm{TiO}_{2}$ films without and with Ge NP modification at different Ge NP concentrations. From the figure, compared with the absorption of the bare $\mathrm{m}-\mathrm{TiO}_{2}$ film, the Ge NP modified $\mathrm{m}-\mathrm{TiO}_{2}$ exhibits a slightly higher absorption range from 350 to $800 \mathrm{~nm}$. The absorption increase with the Ge NP content can be ascribed to the intrinsic absorption of Ge NPs. Fig. 4(b) exhibits the optical absorption spectra of the control $\mathrm{CH}_{3} \mathrm{NH}_{3} \mathrm{PbI}_{3}$ films, as well as the absorber films formed using different Ge NP concentrations. As can be seen in Fig. 4(b), there are no significant differences in the absorption spectra of the control and Ge NP based absorber samples. The result can be attributed to the exceptionally high absorption coefficient

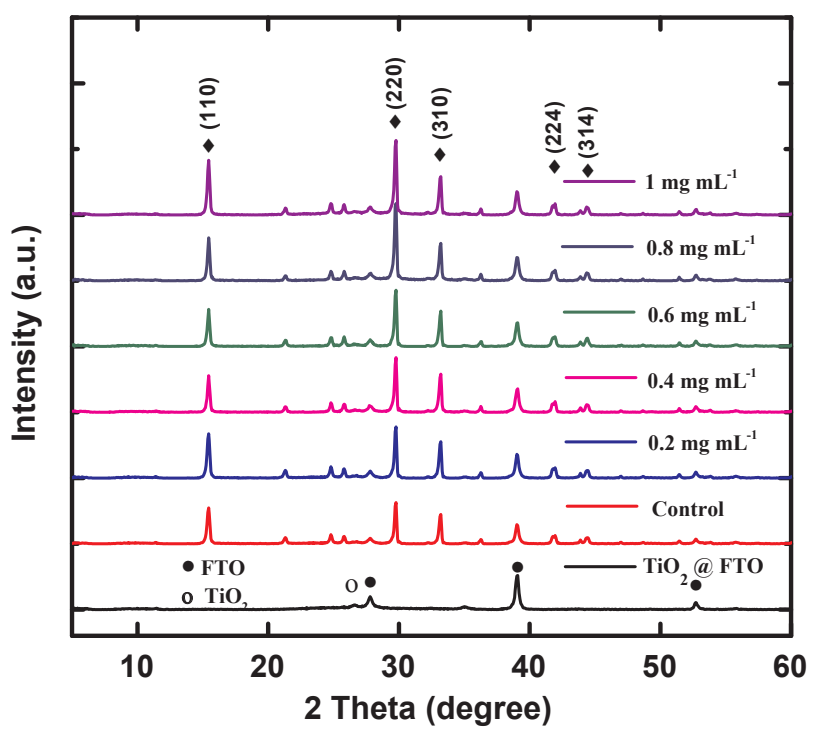

Fig. 2. XRD patterns of perovskite films on the $\mathrm{m}-\mathrm{TiO}_{2} / \mathrm{c}-\mathrm{TiO}_{2} / \mathrm{FTO}$ substrates modified with different concentrations of Ge NP solution. 
(a)

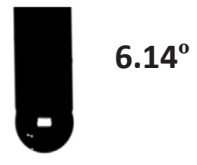

(b)

b)

$16.26^{\circ}$

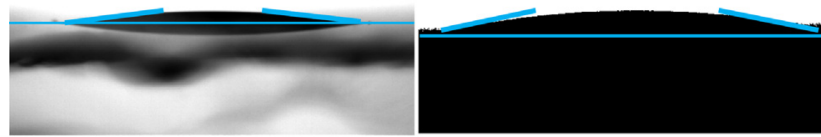

(c)

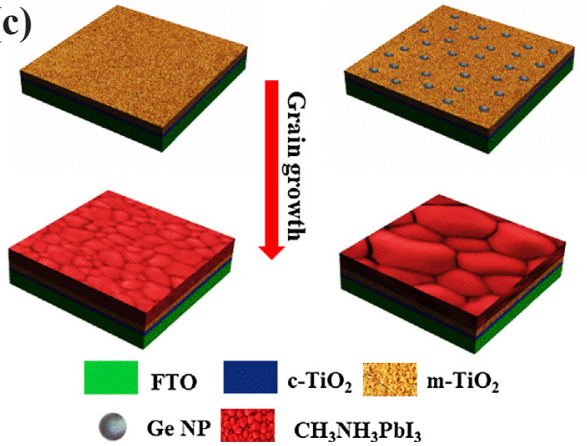

Fig. 3. The contact angle of water on (a) the bare $\mathrm{m}-\mathrm{TiO}_{2}$ film without Ge NP and (b) the $\mathrm{m}-\mathrm{TiO}_{2}$ film modified with $0.4 \mathrm{mg} \mathrm{mL}{ }^{-1} \mathrm{Ge}$ NPs. (c) Schematic illustration of nucleation and growth of perovskite grains on $\mathrm{m}-\mathrm{TiO}_{2}$ films without and with Ge NP modification.

of perovskite $\mathrm{CH}_{3} \mathrm{NH}_{3} \mathrm{PbI}_{3}$ and the small amount of Ge NPs loaded on the $\mathrm{m}-\mathrm{TiO}_{2}$.

In order to probe the crystalline quality connected photo-electronic characteristics of the perovskite absorber layers, steady-state and timeresolved photoluminescence (PL) studies were carried out. Fig. 5(a) shows the PL spectra of $\mathrm{CH}_{3} \mathrm{NH}_{3} \mathrm{PbI}_{3}$ films on $\mathrm{m}$ - $\mathrm{TiO}_{2}$ electrodes modified with different amounts of Ge NPs. Based on the quenching intensities of the perovskite films onto the bare $\mathrm{TiO}_{2} / \mathrm{FTO}$ and the Ge NP modified $\mathrm{TiO}_{2}$ /FTO with different amounts of Ge NPs in the PL spectra, the electron extracting capability of the ETL in solar cells can be appraised, where lower PL intensity of perovskite film on ETL tells more intense electron extraction of ETL (Zhu et al., 2013; Zhao et al., 2016). From Fig. 5(a), the PL intensity displays a downward-upward trend as the Ge NP amount increases from 0 (control) to $1.0 \mathrm{mg} \mathrm{mL}^{-1}$. Comparing with the perovskite film onto the bare $\mathrm{TiO}_{2}$ ETLs, the perovskite film attached onto the Ge NP-TiO ${ }_{2}$ ETL demonstrates a more distinct quenching effect in PL spectrum with the increase of the Ge NP amount from 0 (control) to $0.4 \mathrm{mg} \mathrm{mL}^{-1}$, indicating more effectively quenching the PL of $\mathrm{CH}_{3} \mathrm{NH}_{3} \mathrm{PbI}_{3}$. Further increase in the Ge NP amount from $0.4 \mathrm{mg} \mathrm{mL}^{-1}$ resulted in a distinguishably higher PL intensity. Notably, the perovskite film obtained with $1.0 \mathrm{mg} \mathrm{mL}^{-1} \mathrm{Ge}$ NPs exhibits the highest PL signal, and the corresponding PVSC device is expected to show a higher recombination rate of carriers than the cells based on the other samples. In contrast, the perovskite sample obtained with $0.4 \mathrm{mg} \mathrm{mL}^{-1} \mathrm{Ge}$ NPs shows the lowest peak intensity and the most intense degree of PL quenching, meaning the fastest charge transfer, the most effective electron extraction and the lowest charge accumulation, and thus prospectively the highest short-circuit current and the best PV performance. Therefore, the incorporation of Ge NPs into $\mathrm{m}-\mathrm{TiO}_{2}$ in a proper ratio can provide the driving force for efficient charge extraction from $\mathrm{CH}_{3} \mathrm{NH}_{3} \mathrm{PbI}_{3}$ to $\mathrm{TiO}_{2}$ ETLs.

Fig. 5(b) shows the PL decay profiles following picosecond pulse laser excitation of the perovskite films on bare $\mathrm{TiO}_{2} / \mathrm{FTO}$ and Ge NP$\mathrm{TiO}_{2} / \mathrm{FTO}$ with different amounts of Ge NPs. All decay curves can be well-fitted using a two-exponential equation, yielding a fast decay characterized by the lifetime, $\tau_{1}$, together with a slow component, $\tau_{2}$. All the simulated data are listed in Table 1 . The decay represents and unravels the dynamics of charge transfer processes and charge recombination taken place in the perovskite capping layer and at the interface of $\mathrm{CH}_{3} \mathrm{NH}_{3} \mathrm{PbI}_{3} / \mathrm{m}-\mathrm{TiO}_{2}$. The $\tau_{\text {ave }}$ value of the perovskite sample first decreases and then increases with the increase of the Ge NP amount from 0 (control) to $1.0 \mathrm{mg} \mathrm{mL}^{-1}$. The $\tau_{\text {ave }}$ value of the control perovskite film is $8.19 \mathrm{~ns}$, while the $\tau_{\text {ave }}$ value is considerably increased to $12.37 \mathrm{~ns}$ upon addition of Ge NPs onto $\mathrm{m}-\mathrm{TiO}_{2}$ at a high concentration of $1.0 \mathrm{mg} \mathrm{mL}^{-1}$, in spite of the larger grain crystals formed in the perovskite capping layer shown in Fig. 1(f). This result suggests a relatively high density of charge-carrier trap states and slow electron transfer process in the porous layer under the perovskite capping film and at the interface of $\mathrm{CH}_{3} \mathrm{NH}_{3} \mathrm{PbI}_{3} / \mathrm{m}-\mathrm{TiO}_{2}$. Interestingly, the $\tau_{\text {ave }}$ values of the Ge NP based perovskite samples from $0.4 \mathrm{mg} \mathrm{mL}^{-1} \mathrm{Ge}$ NPs are much shorter than that of the control $\mathrm{CH}_{3} \mathrm{NH}_{3} \mathrm{PbI}_{3}$ film. The abbreviated PL decays indicate rapider electron transport, more effective electron extraction, and a lower defect concentration (Heo et al., 2015); which is in good agreement with higher short-circuit current density, fill factor and PCE values for the corresponding PVSCs (Zhang et al., 2002) presented in the next sections.

The trap state density of the perovskite samples were also examined by the space-charge-limited current (SCLC) technique. We have fabricated electron-only devices $\left(\mathrm{FTO} / \mathrm{c}-\mathrm{TiO}_{2} / \mathrm{m}-\mathrm{TiO}_{2} @ \mathrm{Ge} \mathrm{NPs} /\right.$ $\mathrm{CH}_{3} \mathrm{NH}_{3} \mathrm{PbI}_{3} / \mathrm{AgAl}$ ). Fig. 6(a) shows the SCLC curves of the devices prepared using different concentrations of Ge NPs. The curves can be divided into three different regimes, i.e., ohmic $(n=1)$, SCLC $(n=2)$ and trap-filled limited $(1<\mathrm{n}<2)$ regions according to the diverse values of the exponent $n\left(J \propto V_{\mathrm{n}}\right.$ relation) (Azam et al., 2018). At a kink

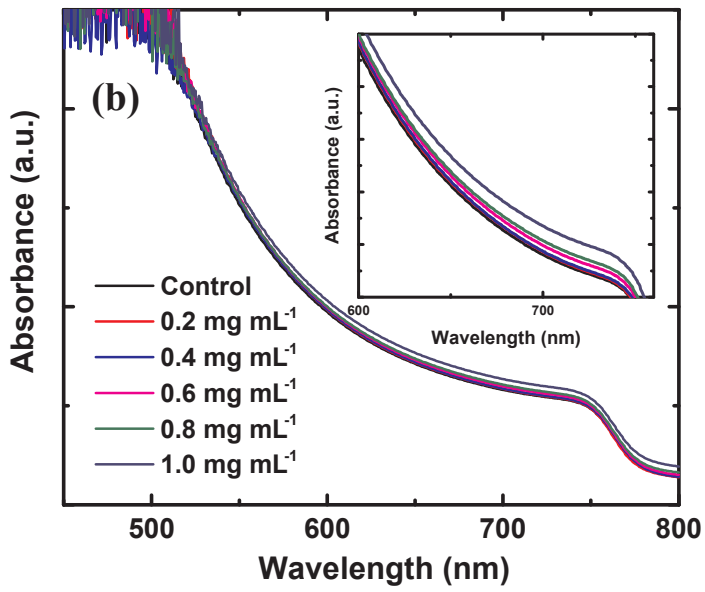

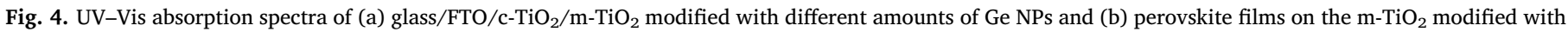
different amounts of Ge NPs. 

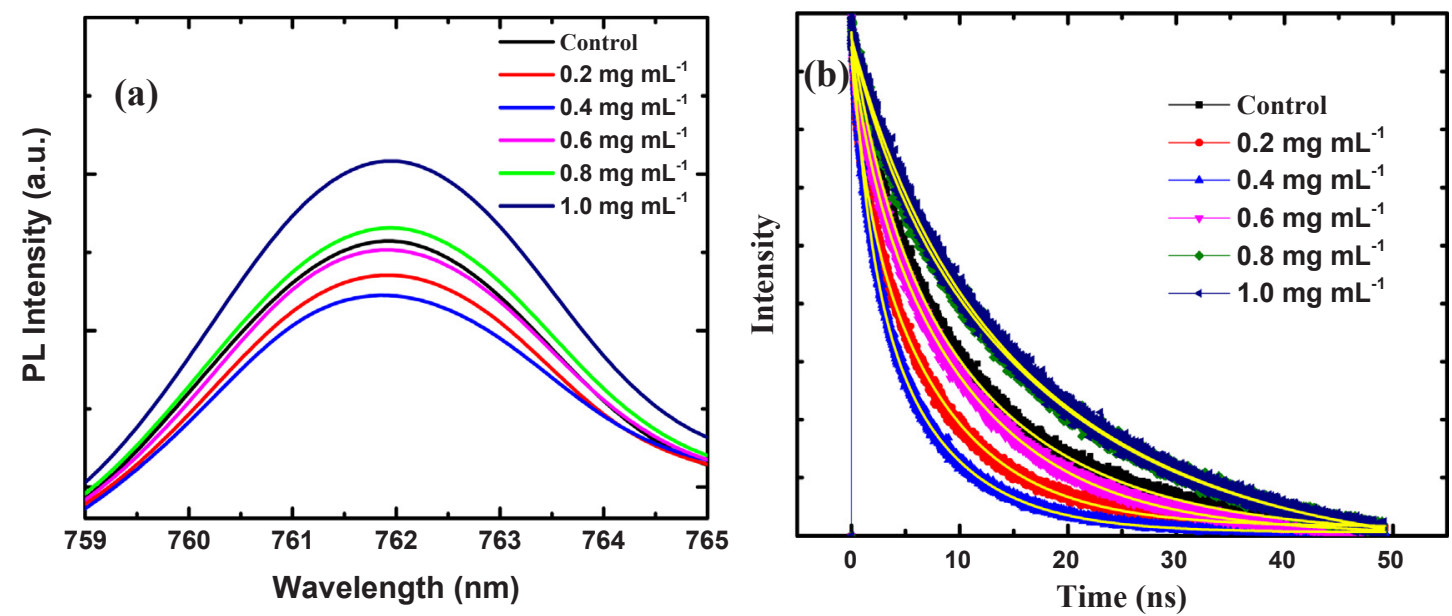

Fig. 5. (a) Steady-state and (b) time resolved PL spectra of $\mathrm{CH}_{3} \mathrm{NH}_{3} \mathrm{PbI}_{3}$ films on the bare $\mathrm{TiO}_{2} / \mathrm{FTO}$ and the Ge $\mathrm{NP}$ coated TiO $2 / \mathrm{FTO}$ with different amounts of Ge NPs.

Table 1

The fitting results of TRPL spectra shown in Fig. 5(b).

\begin{tabular}{llllll}
\hline Samples & $\tau_{1}(\mathrm{~ns})$ & $\tau_{2}(\mathrm{~ns})$ & $\mathrm{A}_{1}(\%)$ & $\mathrm{A}_{2}(\%)$ & $\tau_{\text {ave }}(\mathrm{ns})$ \\
\hline Control & 3.41 & 12.97 & 25.97 & 74.03 & 8.19 \\
$0.2 \mathrm{mg} \mathrm{mL}^{-1} \mathrm{Ge} \mathrm{NPs}$ & 1.91 & 8.05 & 21.58 & 78.42 & 4.98 \\
$0.4 \mathrm{mg} \mathrm{mL}^{-1} \mathrm{Ge} \mathrm{NPs}$ & 1.65 & 6.98 & 39.32 & 60.68 & 4.32 \\
$0.6 \mathrm{mg} \mathrm{mL}^{-1} \mathrm{Ge} \mathrm{NPs}$ & 1.90 & 10.71 & 16.48 & 83.52 & 6.32 \\
$0.8 \mathrm{mg} \mathrm{mL}^{-1} \mathrm{Ge} \mathrm{NPs}$ & 3.73 & 18.51 & 16.08 & 83.92 & 11.12 \\
$1.0 \mathrm{mg} \mathrm{mL}^{-1} \mathrm{Ge} \mathrm{NPs}$ & 5.28 & 19.45 & 18.57 & 81.43 & 12.37 \\
\hline
\end{tabular}

The $\tau_{\text {ave }}$ is calculated by the formula, $\tau_{\text {ave }}=\sum_{i} A_{i} \tau_{i} / \sum_{i} A_{i}$.

point where the current abruptly rises, the bias voltage is defined as the trap-filled limit voltage $\left(V_{\mathrm{TFL}}\right)$. From this domain, the trap density $\left(n_{\text {trap }}\right)$ can be calculated using the following equation: (Lampert, 1956; Li et al., 2017)

$V_{T E F}=\frac{e n_{\text {trap }} L^{2}}{2 \varepsilon_{0} \varepsilon}$

where $L$ is the thickness of the perovskite film, $\varepsilon$ is the relative dielectric constant of $\mathrm{CH}_{3} \mathrm{NH}_{3} \mathrm{PbI}_{3}, \varepsilon_{0}$ is the vacuum permittivity, and e is the elementary charge. The $V_{\mathrm{TFL}}$ values of provskite films prepared by different Ge NP concentrations of 0, 0.2, 0.4, 0.6, 0.8 and $1.0 \mathrm{mg} \mathrm{mL}^{-1}$ are $0.62,0.56,0.53,0.6,0.64$, and $0.65 \mathrm{~V}$, respectively. The corresponding electron trap-density is $8.69 \times 10^{16}, 7.85 \times 10^{16}$, $7.43 \times 10^{16}, 8.41 \times 10^{16}$, and $9.11 \times 10^{16} \mathrm{~cm}^{-3}$, respectively. The defect density of the perovskite film from $0.4 \mathrm{mg} \mathrm{mL}^{-1} \mathrm{Ge}$ NPs is obviously lower than other absorber films. The significantly lower trap density $n_{\text {trap }}$ in perovskite films fabricated from $0.4 \mathrm{mg} \mathrm{mL}^{-1} \mathrm{Ge}$ NPs is consistent with the abbreviated PL decays, the enhanced crystal quality and PL quenching effect presented in the previous sections. The shortened PL decay, the enhanced PL quenching and lower trap state density should be associated with the Ge NP additive assisted crystal growth dynamics, which collaboratively promote the crystal quality and decrease the competition from non-radiative recombination, thus contributing to enhance the photovoltaic performance of the solar cells shown in the next paragraph. At high bias voltages, the current quadratically rises with the voltage in the SCLC region $(n=2)$. From this regime, the charge carrier mobility can be evaluated by the Mott-Gurney law in the single-carrier devices. The mobility can be calculated by the following equation: (Dong et al., 2015)

$J_{D}=\frac{9}{8} \varepsilon_{0} \varepsilon \mu \frac{V^{2}}{L^{3}}$

where $J_{\mathrm{D}}, \mu$ and $V$ are the dark current, mobility and bias voltage,
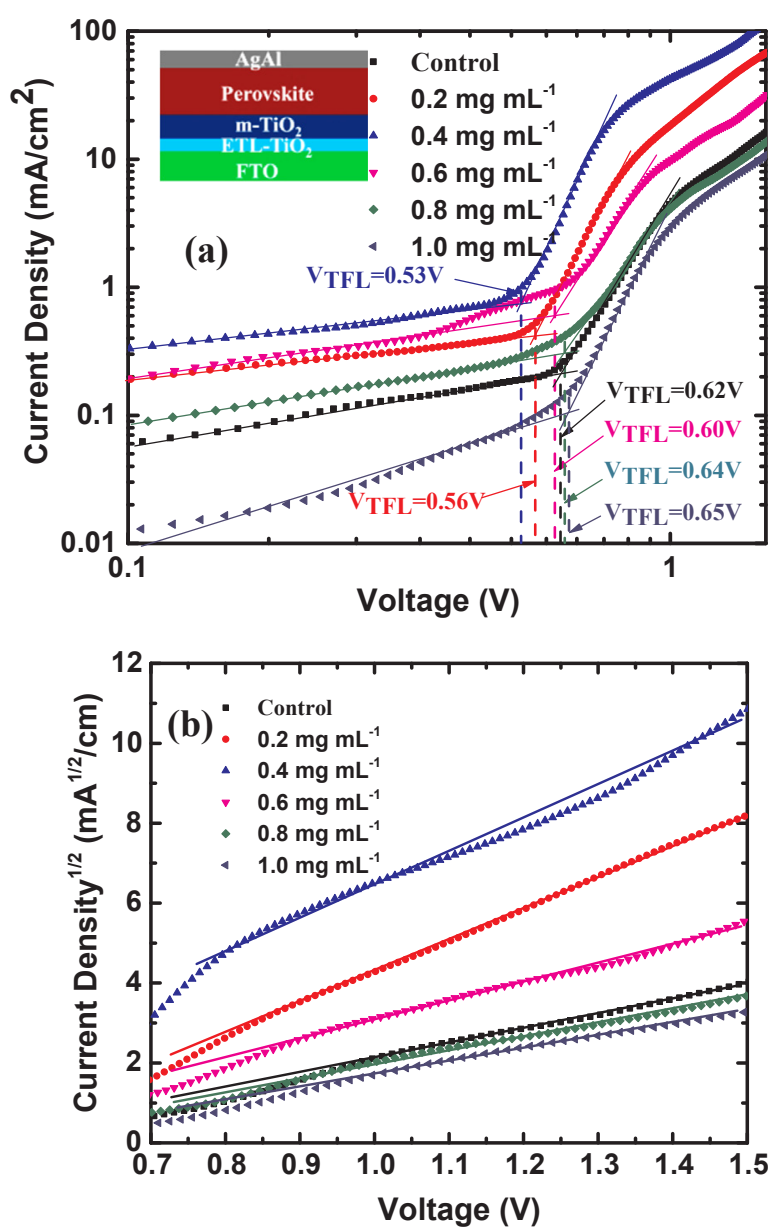

Fig. 6. (a) Dark $J-V$ characteristics of electron-only devices based on perovskite films with different concentrations of Ge NPs. (b) The corresponding $J^{1 / 2}-V$ curves.

respectively. The corresponding $J^{1 / 2}-V$ characteristic curves are given in the Fig. $6(\mathrm{~b})$. A higher slop of $J^{1 / 2}-V$ curve produces a larger mobility. The electron $\mu$ values of the electron-only devices prepared by different Ge NP concentrations of $0,0.2,0.4,0.6,0.8$ and $1.0 \mathrm{mg} \mathrm{mL}^{-1}$ are $1.72 \times 10^{-3}, 6.69 \times 10^{-3}, 8.72 \times 10^{-3}, 2.96 \times 10^{-3}, 1.08 \times 10^{-3}$, and $8.21 \times 10^{-4} \mathrm{~cm}^{2} \mathrm{~V}^{-1} \mathrm{~s}^{-1}$, respectively. The electron mobility value of the perovskite film from $0.4 \mathrm{mg} \mathrm{mL}^{-1} \mathrm{Ge}$ NPs is the highest, 

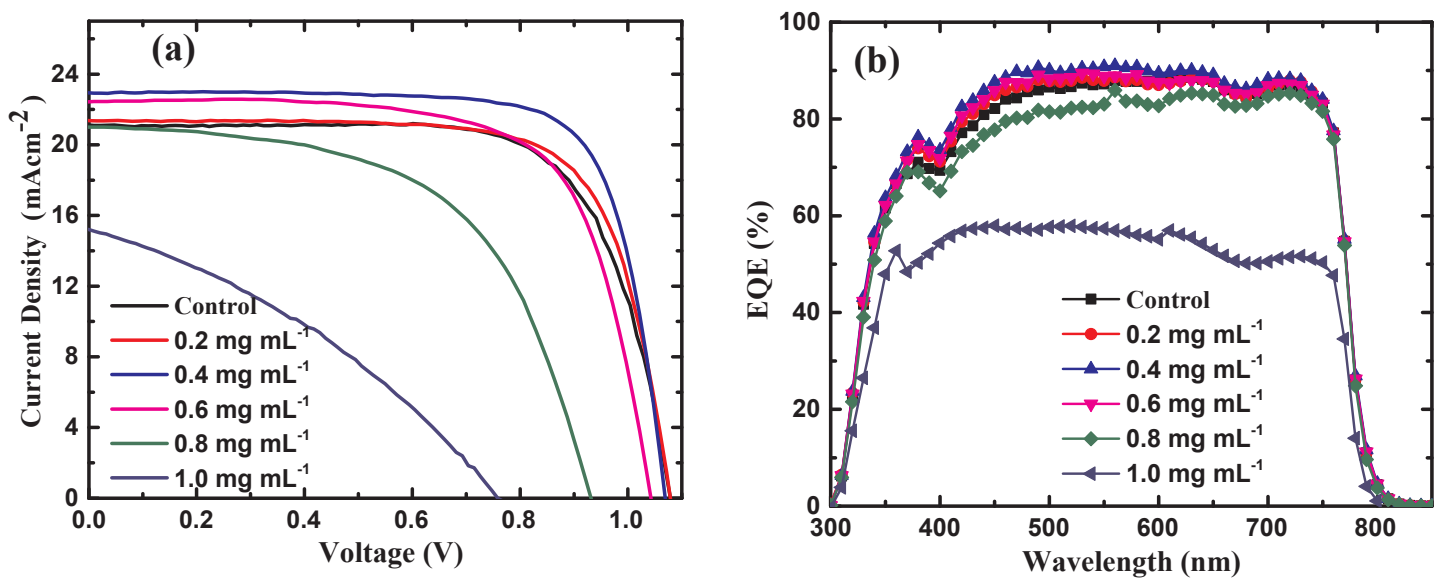

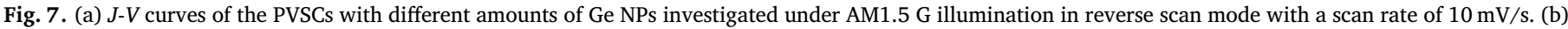
the corresponding EQE spectra.

which is over 5 times higher than the control absorber without Ge NP modification. When the Ge NP concentration is higher than $0.4 \mathrm{mg} \mathrm{mL}^{-1}$, deterioration would be generated in charge carrier mobility for the device.

In order to examine the PV performance of the solar cell applying Ge NPs as an additive to engineer high quality perovskite absorber films, PVSC solar cells were constructed in the mesoporous device configuration of glass/FTO/c-TiO ${ }_{2} / \mathrm{m}-\mathrm{TiO}_{2} @ \mathrm{Ge} \quad \mathrm{NPs} \quad \mathrm{MAPbI}_{3} \quad /$ SpiroOMeTAD/AgAl. Different Ge NP concentrations were used to modify the $\mathrm{m}-\mathrm{TiO}_{2}$ electrodes. The clear-cut layer by layer stacking architecture is displayed by the SEM image, as shown in Fig. 1(g) and (h). The representative $J-V$ curves and the corresponding average PV parameters and the performance dependence on Ge NP concentrations have been determined, and the results are shown in Fig. 7(a) and summarized in Table 2. All the PV parameters including PCE, open-circuit voltage $\left(V_{\mathrm{OC}}\right)$, short-circuit current density $\left(J_{\mathrm{SC}}\right)$, fill factor $(\mathrm{FF})$, series $\left(R_{\mathrm{S}}\right)$ and shunt $\left(R_{\mathrm{SH}}\right)$ resistances are listed in Table 2. The PVSCs based on the bare $\mathrm{m}-\mathrm{TiO}_{2}$ produced an average PCE of $16.24 \%$, and the corresponding cells based on the $0.2 \mathrm{mg} \mathrm{mL}^{-1} \mathrm{Ge}$ NPs generated a little higher FF and $J_{\mathrm{SC}}$, leading to a slightly enhanced average PCE of $16.78 \%$. Particularly, as the concentration of Ge NPs was increased to $0.4 \mathrm{mg} \mathrm{mL}^{-1}$, much more significant enhancements in $J_{\mathrm{SC}}$ and FF were achieved. Specifically, the $J_{\mathrm{SC}}$ increased from 21.10 to $22.93 \mathrm{~mA} \mathrm{~cm}^{-2}$, and most conspicuously the $\mathrm{FF}$ increased from $71.42 \%$ to $75.91 \%$, reaching an average PCE of $18.59 \%$. However, a successive increase in the amount of Ge NPs from $0.4 \mathrm{mg} \mathrm{mL}^{-1}$ to $1.0 \mathrm{mg} \mathrm{mL}^{-1}$ caused a continuously reduced $V_{\mathrm{OC}}, J_{\mathrm{SC}}$ and PCE, in spite of the larger grain crystals formed in the capping layer compared with the case at $0.4 \mathrm{mg} \mathrm{mL}^{-1} \mathrm{Ge}$ NPs. Specifically, at the concentration of $1.0 \mathrm{mg} \mathrm{mL}^{-1}$, a dramatically decrease in $J_{\mathrm{SC}}, V_{\mathrm{OC}}$ and FF was noticed, resulting in a tremendous shrinkage in PCE to 3.99\%, although largest grain crystals were formed in the capping layer as shown in Fig. 1(f). This decrease in the PV performance may be linked with the surface natures of $\mathrm{m}-\mathrm{TiO}_{2}$ electrodes modified with high Ge NP concentration. The first feature is with the too highly hydrophobic nature of Ge NP based $\mathrm{m}-\mathrm{TiO}_{2}$ electrode surface at the high Ge NP concentration. Secondly, overmuch Ge NPs cover and block the pores of $\mathrm{m}^{-\mathrm{TiO}_{2}}$ at the extra high Ge NP concentration. Both properties do not facilitate the loading of perovskite into the $\mathrm{m}-\mathrm{TiO}_{2}$ pores in the mesoporous device, decreasing the contact area between the perovskite and $\mathrm{m}-\mathrm{TiO}_{2}$ and leading to trap states in the porous layer under the perovskite capping film and at the interface of $\mathrm{CH}_{3} \mathrm{NH}_{3} \mathrm{PbI}_{3} / \mathrm{m}$ - $\mathrm{TiO}_{2}$, as confirmed by steady-state $\mathrm{PL}$, time-resolved PL and SCLC measurement results shown in Fig. 5, Table 1 and Fig. 6, respectively. The big contacting angle and highly nonwetting surface of Ge NP based $\mathrm{m}^{-\mathrm{TiO}_{2}}$ ETL at a too high Ge NP content $\left(>0.6 \mathrm{mg} \mathrm{mL}^{-1}\right)$ is not beneficial for pore-filling of the perovskite semiconductor, leading to deteriorated charge separation at the interface of $\mathrm{CH}_{3} \mathrm{NH}_{3} \mathrm{PbI}_{3} / \mathrm{TiO}_{2}$ (Kim et al., 2013). The optimized Ge NP concentration was found to be $0.4 \mathrm{mg} \mathrm{mL}^{-1}$, and the corresponding optimal device displays a PCE of $18.59 \%$, resulting from a $V_{\mathrm{OC}}$ of $1.06 \mathrm{~V}, J_{\mathrm{SC}}$ of $22.93 \mathrm{~mA} \mathrm{~cm}^{-2}$ and FF of $75.91 \%$. Actually, the best PCE of $19.6 \%$ was attained via using GE NPs as adduct on the $\mathrm{m}-\mathrm{TiO}_{2}$. The optimized device has the lowest series and the highest shunt resistances shown in Table 2, thus indicating the best diode behavior. The $J_{\mathrm{SC}}$ values extracted from the $J-V$ characteristics for each cell are substantiated by the EQE spectra in Fig. 7(b). The best EQE performance is acquired at $0.4 \mathrm{mg} \mathrm{mL}^{-1} \mathrm{Ge}$ NPs, exhibiting a wide plateau with a maximal value of $91.02 \%$ over the entire visible-light regime. With an increment in the Ge NP concentration from 0 to $0.4 \mathrm{mg} \mathrm{mL}^{-1}$, the device demonstrated more and more heightened EQE value at the short wavelength range from $350 \mathrm{~nm}$ to $750 \mathrm{~nm}$, which was in good agreement with the photocurrent density result from the $J-V$ curves shown in Fig. 7(a). A further increase in the amount of Ge NPs from $0.6 \mathrm{mg} \mathrm{mL}^{-1}$, despite the further increased size of perovskite grains in the capping layer of the absorber, leads to a dramatically reduced EQE over the whole wavelength region from $350 \mathrm{~nm}$ to $750 \mathrm{~nm}$. This decrease can be associated with the deteriorated charge transport and collection/separation due to the poor pore-filling of perovskite into $\mathrm{m}-\mathrm{TiO}_{2}$ and numerous trap sites harbored in the device at high concentration of $\mathrm{Ge}$ NPs.

Table 2

Average Device performance parameters of PVSC devices with different amounts of Ge NPs investigated under AM $1.5 \mathrm{G}$ Illumination $\left(100 \mathrm{~mW} \mathrm{~cm}^{-2}\right)$.

\begin{tabular}{|c|c|c|c|c|c|c|}
\hline Device & $V_{\mathrm{OC}}(\mathrm{V})$ & $J_{\mathrm{SC}}\left(\mathrm{mA} \mathrm{cm}{ }^{-2}\right)$ & FF (\%) & PCE (\%) & $\mathrm{R}_{\mathrm{S}}(\Omega)$ & $\mathrm{R}_{\mathrm{SH}}(\Omega)$ \\
\hline Control & $1.08 \pm 0.04$ & $21.10 \pm 0.53$ & $71.42 \pm 2.24$ & $16.24 \pm 1.60$ & $52 \pm 4$ & $11,372 \pm 61$ \\
\hline $0.2 \mathrm{mg} \mathrm{mL}^{-1} \mathrm{Ge}$ NPs & $1.07 \pm 0.03$ & $21.36 \pm 0.45$ & $72.91 \pm 3.22$ & $16.78 \pm 1.48$ & $48 \pm 9$ & $32,148 \pm 45$ \\
\hline $0.4 \mathrm{mg} \mathrm{mL}^{-1} \mathrm{Ge}$ NPs & $1.06 \pm 0.04$ & $22.93 \pm 0.11$ & $75.91 \pm 2.34$ & $18.59 \pm 1.24$ & $35 \pm 4$ & $41,482 \pm 63$ \\
\hline $0.6 \mathrm{mg} \mathrm{mL}^{-1} \mathrm{Ge}$ NPs & $1.04 \pm 0.01$ & $22.42 \pm 0.22$ & $69.76 \pm 3.59$ & $16.34 \pm 1.09$ & $47 \pm 3$ & $16,484 \pm 42$ \\
\hline $0.8 \mathrm{mg} \mathrm{mL}^{-1} \mathrm{Ge} \mathrm{NPs}$ & $0.93 \pm 0.02$ & $20.98 \pm 0.37$ & $57.00 \pm 2.78$ & $11.12 \pm 0.59$ & $84 \pm 4$ & $7567 \pm 67$ \\
\hline $1.0 \mathrm{mg} \mathrm{mL}^{-1} \mathrm{Ge} \mathrm{NPs}$ & $0.75 \pm 0.04$ & $15.11 \pm 0.46$ & $34.86 \pm 4.34$ & $3.99 \pm 0.83$ & $262 \pm 9$ & $8468 \pm 44$ \\
\hline
\end{tabular}




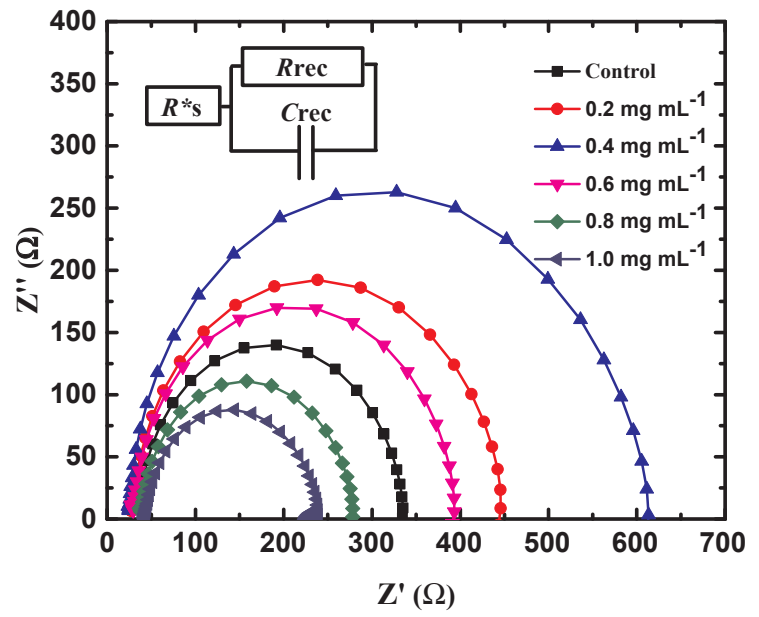

Fig. 8. EIS of PVSC devices with different concentrations of Ge NPs in dark conditions.

The perovskite capping layer shows larger grain size and higher crystallinity when the concentration of Ge NPs increases from 0 to $1.0 \mathrm{mg} \mathrm{mL}^{-1}$. Thus, the addition of Ge NPs onto the $\mathrm{m}-\mathrm{TiO}_{2}$ ETL is expected to control nucleation over the perovskite precursor film, improving the grain size and facilitating the perovskite to grow in a preferred direction, with reflection of the facet with $(220)$ and $\left(\begin{array}{ll}1 & 10\end{array}\right)$ indices being dominant. On the other hand, when the Ge NP content is great than $0.6 \mathrm{mg} \mathrm{mL}^{-1}$, the $\mathrm{m}-\mathrm{TiO}_{2}$ electrode surface became too highly hydrophobic, and overmuch Ge NPs covered and blocked the pores of $\mathrm{m}-\mathrm{TiO}_{2}$, impeding pore-filling of the perovskite semiconductor and leading to deteriorated charge separation at the interface of $\mathrm{CH}_{3} \mathrm{NH}_{3} \mathrm{PbI}_{3} / \mathrm{TiO}_{2}$. This phenomenon accounts for the deterioration of the PV performance when the Ge NP content exceeds $0.6 \mathrm{mg} \mathrm{mL}^{-1}$ because the excess of Ge NPs will impair separation and transport of charge carriers.

Electrochemical impedance spectroscopy (EIS) was characterized to understand the difference in the PV performance of the devices based on Ge NP modification. Fig. 8 shows EIS spectra of the devices fabricated with different concentrations of Ge NPs in the dark. The EIS measurements were performed over the frequency range of $10-1 \mathrm{MHz}$ and at a voltage bias of $0.9 \mathrm{~V}$. In the dark, the PVSC device could be treated as a leakage capacitor (Guo et al., 2015; Zhang et al., 2017a). The half-circle symbolizes the recombination resistance $\left(R_{\text {rec }}\right)$ at the interface of perovskite absorber/ $\mathrm{TiO}_{2} \mathrm{ETL}$ or hole-transport layer. An equivalent circuit shown in the inset of Fig. 8 is used to fit the impedance data. $R_{\mathrm{s}}^{*}$ is the ohmic series resistance, which includes the sheet resistance of $\mathrm{TiO}_{2}$ electrode and $\mathrm{CH}_{3} \mathrm{NH}_{3} \mathrm{PbI}_{3}$ absorber. $C_{\text {rec }}$ refers to the chemical capacitance at the interface of perovskite/ $/ \mathrm{TiO}_{2}$. The results of the impedance data are shown in Table 3. In our work, for ohmic series resistance $R_{\text {s }}^{*}$, improved $\mathrm{CH}_{3} \mathrm{NH}_{3} \mathrm{PbI}_{3}$ absorber with high carrier mobility can decrease the resistances. From Table 3 , with the increase of the Ge NP concentration from 0 to $1.0 \mathrm{mg} \mathrm{mL}^{-1}$, the value of $R_{\mathrm{s}}^{*}$ first decreases and then increases. The sample of $1.0 \mathrm{mg} \mathrm{mL}^{-1} \mathrm{Ge}$

Table 3

EIS results of PVSC devices with different concentrations of Ge NPs under dark at a bias of $0.9 \mathrm{~V}$.

\begin{tabular}{llll}
\hline Device & $R_{\mathrm{s}}^{*}(\Omega)$ & $R_{\text {rec }}(\Omega)$ & $C_{\text {rec }}(\mathrm{nF})$ \\
\hline Control & 30.4 & 304.2 & 102.5 \\
$0.2 \mathrm{mg} \mathrm{mL}^{-1} \mathrm{Ge} \mathrm{NPs}$ & 25.8 & 419.9 & 90.3 \\
$0.4 \mathrm{mg} \mathrm{mL}^{-1} \mathrm{Ge} \mathrm{NPs}$ & 23.5 & 589.8 & 75.6 \\
$0.6 \mathrm{mg} \mathrm{mL}^{-1} \mathrm{Ge} \mathrm{NPs}$ & 27.0 & 366.2 & 89.3 \\
$0.8 \mathrm{mg} \mathrm{mL}^{-1} \mathrm{Ge} \mathrm{NPs}$ & 36.3 & 241.8 & 110.9 \\
$1.0 \mathrm{mg} \mathrm{mL}^{-1} \mathrm{Ge} \mathrm{NPs}$ & 43.2 & 195.9 & 126.3 \\
\hline
\end{tabular}

NPs shows the maximal ohmic series resistance, indicating the maximal contact resistance between the $\mathrm{TiO}_{2}$ and active layer. At $0.4 \mathrm{mg} \mathrm{mL}^{-1}$ Ge NPs, the $R_{\mathrm{s}}^{*}$ resistance is the lowest, indicating the highest carrier mobility of the corresponding $\mathrm{CH}_{3} \mathrm{NH}_{3} \mathrm{PbI}_{3}$ absorber. The results are consistent with those from dark $J-V$ characteristics of electron-only devices based on perovskite films with different concentrations of $\mathrm{Ge}$ NPs shown in Fig. 6(a). The low resistance could cause an effective and rapid transporting capability for the photo-generated carriers, which would ultimately promote the PV performance, especially the fill factor of PVSCs. Furthermore, with the rise of the Ge NP concentration from 0 to $1.0 \mathrm{mg} \mathrm{mL}^{-1}$, the diameter of the semicircle increases first and then decreases, which indicates the recombination resistance gradually enlarges and then reduces. The device at $0.4 \mathrm{mg} \mathrm{mL}^{-1} \mathrm{Ge}$ NPs exhibits the largest $R_{\text {rec }}$, indicating the most efficient recombination blocking effect. Thus the device fabricated with $0.4 \mathrm{mg} \mathrm{mL}^{-1}$ Ge NPs could provide the best PV properties, supporting the PV performance results shown in Fig. 7 and Table 2.

Generally, just as metal nanoparticles, semiconductor NPs with a high refractive index and low dissipation in the visible region can be expected to enhance light energy trapping in the thin film solar cell by far-field coupling of scattered light, near-field coupling of localized electromagnetic fields, and even energy transfer (Wintzheimer et al., 2018). Light incident on semoconductor nanoparticles can be scattered into the far-field; depending on geometric and material properties of the particles (Bohren and Huffman, 2008; Fan et al., 2016). Finite-difference time-domain (FDTD) numerical simulations were performed using finite integral technique (FIT) technique (CST Microwave Studio) (Luo et al., 2017; Fan et al., 2016). The optical properties (refractive index, $\mathrm{n}$ and extinction coefficient, $\mathrm{k}$ ) of materials are from the data in previous publications (Luo et al., 2017; Aspnes and Studna, 1983; Johnson and Christy, 1972; Ball et al., 2015). Fig. 9(a) and (b) show the calculated absorption and scattering cross-sections of a spherical Au or Ge nanosphere with a radius (a) of $50 \mathrm{~nm}$ in free space, respectively. It can be seen that Au has stronger absorptive properties in the wavelength $(\lambda)$ range of $300 \mathrm{~nm}-550 \mathrm{~nm}$ than $\mathrm{Ge}$, but the result is inverse at the longer wavelength $(\lambda>550 \mathrm{~nm})$. The scattering efficiency of Au nanosphere peaks at about $520 \mathrm{~nm}$ due to the surface plasmon resonance of Au nanoparticles, as shown in Fig. 9(b). The Ge has a little stronger scattering property than the Au at the shorter wavelength. The near-field enhancement and distribution for Ge nanosphere embedded between $\mathrm{m}-\mathrm{TiO}_{2}$ and provskite layers is simulated. Fig. 9(c) shows the calculated local amplitude enhancement distribution of the electric field $|E|$ in the $x z$ plane with the center of the Ge nanosphere located at the origin. The incident light is with a wavelength of $560 \mathrm{~nm}$, where the maximal absolute EQE value was obtained. The electric field is a slightly enhanced and localized around the Ge nanosphere, and the maximum $|\mathrm{E}|$ enhancement factor is about 1.7 at $560 \mathrm{~nm}$. Therefore, compared to the case of Au NPs embedded PVSCs (Zhang et al., 2013; Saliba et al., 2015; Cheng et al., 2017; Luo et al., 2017), the optical enhancement in Ge NPs based PVSCs from far-field coupling of scattered light and near-field coupling of localized electromagnetic fields should be lower. Even in the plasmonic PVSCs based on the noble metallic nanotructures, it is found that the PV performance enhancements of $\mathrm{Au} @ \mathrm{SiO}_{2}, \mathrm{Au} @ \mathrm{MgO}, \mathrm{Au} @ \mathrm{TiO}_{2}$ composite PVSCs mainly stem from plasmonically enhanced electrical properties of the devices, rather than from optical effects alone (Zhang et al., 2013; Luo et al., 2017; Jang et al., 2016). In this work, no obvious enhancements were observed in the absorption patterns of the perovskite films on the $\mathrm{m}-\mathrm{TiO}_{2}$ modified with different amounts of Ge NPs, as shown in Fig. 4(b). However, EQE measurements exhibited a broadband enhancement over the wavelength range from $350 \mathrm{~nm}$ to $750 \mathrm{~nm}$ at the Ge content less than $0.6 \mathrm{mg} \mathrm{mL}^{-1}$, as shown in Fig. 7(b). The PVSC device with an optimal Ge NP amount of $0.4 \mathrm{mg} \mathrm{mL}^{-1}$ reached an average PCE of $18.59 \%$, exhibiting over $14 \%$ enhancement, compared with the reference device without Ge NPs. The achieved PV enhancement can be correlated to the presence of proper ratio Ge nanoparticles, which 

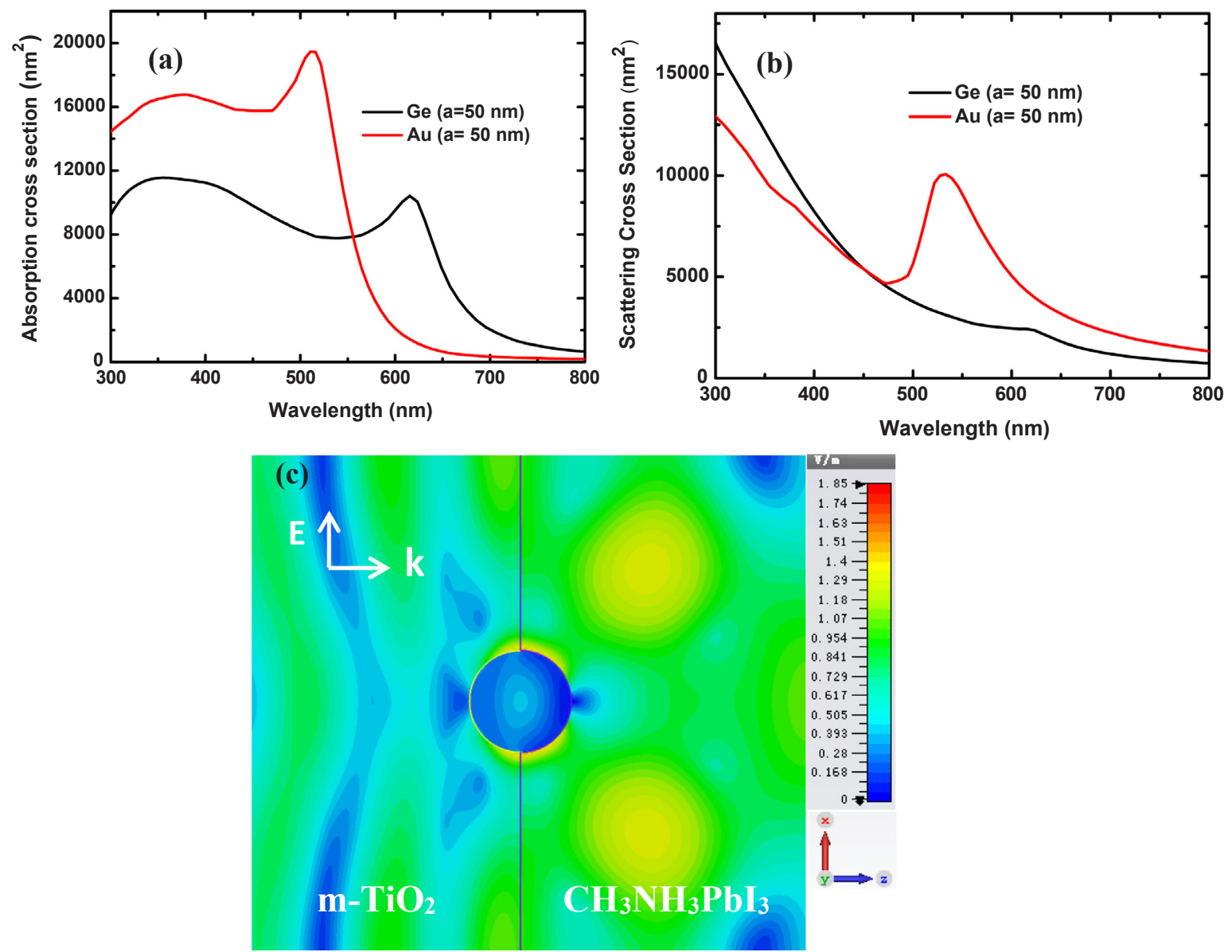

Fig. 9. Calculated absorption (a) and scattering (b) cross sections of Au and Ge nanospheres with a radius of $50 \mathrm{~nm}$. (c) Simulated field $|\mathrm{E}|$ enhancement distribution of $\mathrm{Ge}$ nanosphere $(\mathrm{a}=50 \mathrm{~nm})$ embedded between $\mathrm{m}-\mathrm{TiO}_{2}$ and $\mathrm{CH}_{3} \mathrm{NH}_{3} \mathrm{PbI}_{3}$ layers.

simultaneously improve the morphology and crystallinity of the mesoporous perovskite absorber as well as the interfacial natures of perovskite/ $/ \mathrm{TiO}_{2}$, further significantly enhancing EQE, $J_{\mathrm{SC}}$ and $\mathrm{FF}$ values of PVSCs.

\section{Conclusions}

We have developed a facile, simple and convenient method to effectively deposit high quality and low defect density $\mathrm{CH}_{3} \mathrm{NH}_{3} \mathrm{PbI}_{3}$ perovskite films with improved optoelectronic natures for high-efficiency mesoscopic heterojunction PVSCs. Colloidal Ge NPs were embedded between $\mathrm{m}-\mathrm{TiO}_{2}$ and perovskite layers. The influence of the incorporated Ge NPs on the PV performance of PVSCs have been systematically investigated by a combinatorial evaluation of microstructures of Ge NPs modified porous $\mathrm{TiO}_{2}$ and perovskite films, defect densities and charge transport natures of the perovskite absorber and the interface at $\mathrm{m}-\mathrm{TiO}_{2} / \mathrm{CH}_{3} \mathrm{NH}_{3} \mathrm{PbI}_{3}$. It is found that the addition of $\mathrm{Ge}$ NPs with an optimized concentration simultaneously improved the crystallinity and morphology of the perovskite film as well as the $\mathrm{TiO}_{2}$ perovskite interfacial properties. The more effectively PL quenching, abbreviated PL decay lifetime of $\mathrm{FTO} / \mathrm{c}-\mathrm{TiO}_{2} / \mathrm{m}-\mathrm{TiO}_{2} @ \mathrm{Ge} \mathrm{NPs} /$ $\mathrm{CH}_{3} \mathrm{NH}_{3} \mathrm{PbI}_{3}$ layers and multiple (over five folds) enhanced charge mobility of the perovskite absorber at the optimal Ge NP content strongly confirm our results. Consequently, the incorporation of an optimized ratio Ge NPs in PVSC devices improves the average PCE from 16.24 to $18.59 \%$, displaying over $14 \%$ enhancement compared with the reference cell without Ge NP modification. Our research provides an innovative approach to significantly promote the performance of heterojunction PVSC devices by green semiconductor nanoparticles.

\section{Acknowledgements}

This work was supported by Natural Science Foundation of Shanghai (Nos. 18ZR1411900, 18ZR1411000) and National Natural Science Foundation of China (No. 11274119). Z. B. Wang thanks funding support from the 2nd Solar Photovoltaic Academic Research Consortium (SPARC II), the European Regional Development Fund (ERDF) and the Welsh European Funding Office (WEFO).

\section{Appendix A. Supplementary material}

Supplementary data to this article can be found online at https:// doi.org/10.1016/j.solener.2019.06.069.

\section{References}

Aharon, S., Dymshits, A., Rotem, A., Etgar, L., 2015. Temperature dependence of hole conductor free formamidinium lead iodide perovskite based solar cells. J. Mater. Chem. A 3 (17), 9171-9178.

Akihiro, K., Kenjiro, T., Yasuo, S., Tsutomu, M., 2009. Organometal halide perovskites as visible-light sensitizers for photovoltaic cells. J. Am. Chem. Soc. 131 (17), 6050-6051.

Akimov, Y.A., Koh, W.S., Sian, S.Y., Ren, S., 2010. Nanoparticle-enhanced thin film solar cells: metallic or dielectric nanoparticles? Appl. Phys. Lett. 96 (7), 073111.

Aspnes, D.E., Studna, A.A., 1983. Dielectric functions and optical parameters of Si, Ge, $\mathrm{GaP}, \mathrm{GaAs}, \mathrm{GaSb}$, InP, InAs, and InSb from 1.5 to $6.0 \mathrm{eV}$. Phys. Rev. B 27, 985.

Azam, M., Yue, S., Rui, X.U., Kong, L., Ren, K., Sun, Y., Liu, J., Wang, Z., Qu, S., Lei, Y., 2018. Highly efficient solar cells based on $\mathrm{Cl}$ incorporated tri-cation perovskite materials. J. Mater. Chem. A 6 (28), 13725-13734.

Ball, J.M., Stranks, S.D., Hörantner, M.T., Hüttner, S., Zhang, W., Crossland, E.J., Ramirez, I., Riede, M., Johnston, M.B., Friend, R.H., 2015. Optical properties and limiting photocurrent of thin-film perovskite solar cells. Energy Environ. Sci. 8 (2), 602-609.

Bi, D., Tress, W., Dar, M.I., Peng, G., Luo, J., Renevier, C., Schenk, K., Abate, A., Giordano, 
F., Baena, J.P.C., 2016. Efficient luminescent solar cells based on tailored mixedcation perovskites. Sci. Adv. 2 (1), e1501170.

Bi, D., Luo, J., Zhang, F., Magrez, A., Athanasopoulou, E.N., Hagfeldt, A., Grätzel, M., 2017. Morphology engineering: a route to highly reproducible and high efficiency perovskite solar cells. ChemSusChem 10 (7), 1624-1630.

Bi, D., Li, X., Milić, J.V., Kubicki, D.J., Pellet, N., Luo, J., LaGrange, T., Mettraux, P., Emsley, L., Zakeeruddin, S.M., 2018. Multifunctional molecular modulators for perovskite solar cells with over $20 \%$ efficiency and high operational stability. Nat. commun. 9 (4482), 4482.

Bi, C., Wang, Q., Shao, Y., Yuan, Y., Xiao, Z., Huang, J., 2015. Non-wetting surface-driven high-aspect-ratio crystalline grain growth for efficient hybrid perovskite solar cells. Nat. Commun. 6, 7747.

Bohren, C.F., Huffman, D.R., 2008. Absorption and Scattering of Light by Small Particles. John Wiley \& Sons.

Bontempi, N., Chong, K.E., Orton, H.W., Staude, I., Choi, D.-Y., Alessandri, I., Kivshar, Y.S., Neshev, D.N., 2017. Highly sensitive biosensors based on all-dielectric nanoresonators. Nanoscale 9 (15), 4972-4980.

Caldarola, M., Albella, P., Cortés, E., Rahmani, M., Roschuk, T., Grinblat, G., Oulton, R.F., Bragas, A.V., Maier, S.A., 2015. Non-plasmonic nanoantennas for surface enhanced spectroscopies with ultra-low heat conversion. Nat. Commun. 6, 7915.

Carreteropalacios, S., Jiménezsolano, A., Míguez, H., 2016. Plasmonic nanoparticles as light-harvesting enhancers in perovskite solar cells: a user's guide. ACS Energy Lett. 1 (1), 323-331.

Cheng, Y., Chen, C., Chen, X., Jin, J., Li, H., Song, H., Dai, Q., 2017. Considerably enhanced perovskite solar cells by introduction of metallic nanostructures. J. Mater. Chem. A 5 (14), 6515-6521.

Domanski, K., Correabaena, J.P., Mine, N., Nazeeruddin, M.K., Abate, A., Saliba, M., Tress, W., Hagfeldt, A., Grätzel, M., 2016. Not all that glitters is gold: metal-migration-induced degradation in perovskite solar cells. ACS Nano 10 (6), 6306-6314.

Dong, Q., Fang, Y., Shao, Y., Mulligan, P., Qiu, J., Cao, L., Huang, J., 2015. Electron-hole diffusion lengths $>175 \mu \mathrm{m}$ in solution grown $\mathrm{CH}_{3} \mathrm{NH}_{3} \mathrm{PbI}_{3}$ single crystals. Science 347 (6225), 967-970.

Fan, W., Yan, B., Wang, Z., Wu, L., 2016. Three-dimensional all-dielectric metamaterial solid immersion lens for subwavelength imaging at visible frequencies. Sci. Adv. 2 (8), e1600901.

Green, M.A., Hishikawa, Y., Dunlop, E.D., Levi, D.H., Hohl-Ebinger, J., Ho-Baillie, A.W., 2018. Solar cell efficiency tables (version 52). Prog. Photovoltaics 26 (7), 427-436.

Guo, X., Dong, H., Li, W., Li, N., Wang, L., 2015. Multifunctional MgO layer in perovskite solar cells. ChemPhysChem 16 (8), 1727-1732.

Heo, J.H., Song, D.H., Han, H.J., Kim, S.Y., Kim, J.H., Kim, D., Shin, H.W., Ahn, T.K., Wolf, C., Lee, T.W., 2015,. Planar $\mathrm{CH}_{3} \mathrm{NH}_{3} \mathrm{PbI}_{3}$ perovskite solar cells with constant $17.2 \%$ average power conversion efficiency irrespective of the scan rate. Adv. Mater 27 (22), 3424-3430.

Im, J.-H., Lee, C.-R., Lee, J.-W., Park, S.-W., Park, N.-G., 2011. 6.5\% efficient perovskite quantum-dot-sensitized solar cell. Nanoscale 3 (10), 4088-4093.

Jahani, S., Jacob, Z., 2016. All-dielectric metamaterials. Nat. nanotechnol. 11 (1), 23.

Jang, Y.H., Jang, Y.J., Kim, S., Quan, L.N., Chung, K., Kim, D.H., 2016. Plasmonic solar cells: from rational design to mechanism overview. Chem. Rev. 116 (24), 14982-15034.

Johnson, P.B., Christy, R.-W., 1972. Optical constants of the noble metals. Phys. Rev. B 6, 4370.

Kakavelakis, G., Petridis, C., Kymakis, E., 2017. Recent advances in plasmonic metal and rare-earth-element upconversion nanoparticles doped perovskite solar cells. J. Mater. Chem. A 5 (41), 21604-21624.

Kim, H.-S., Lee, J.-W., Yantara, N., Boix, P.P., Kulkarni, S.A., Mhaisalkar, S., Grätzel, M., Park, N.-G., 2013. High efficiency solid-state sensitized solar cell-based on submicrometer rutile $\mathrm{TiO}_{2}$ nanorod and $\mathrm{CH}_{3} \mathrm{NH}_{3} \mathrm{PbI}_{3}$ perovskite sensitizer. Nano lett. 13 (6), 2412-2417.

Kuznetsov, A.I., Miroshnichenko, A.E., Fu, Y.H., Zhang, J., Luk’Yanchuk, B., 2012. Magnetic light. Sci. Rep. 2, 492.

Kuznetsov, A.I., Miroshnichenko, A.E., Brongersma, M.L., Kivshar, Y.S., Luk'Yanchuk, B., 2016. Optically resonant dielectric nanostructures. Science 354 (6314), 2472.

Lampert, M.A., 1956. Simplified theory of space-charge-limited currents in an insulator with traps. Phys. Rev. 103 (6), 1648.

Lee, D.S., Kim, W., Cha, B.G., Kwon, J., Kim, S.J., Kim, M., Kim, J., Wang, D.H., Park, J.H., 2016. Self-position of Au NPs in perovskite solar cells: optical and electrical contribution. ACS Appl. Mater. Interfaces 8 (1), 449-454.

Lee, M.M., Teuscher, J., Miyasaka, T., Murakami, T.N., Snaith, H.J., 2012. Efficient hybrid solar cells based on meso-superstructured organometal halide perovskites. Science 338 (6107), 643-647.

Lei, J., Gao, F., Wang, H., Li, J., Jiang, J., Wu, X., Gao, R., Yang, Z., Liu, S.F., 2018. Efficient planar CsPbBr 3 perovskite solar cells by dual-source vacuum evaporation. Sol. Energy Mater. Sol. Cells 187, 1-8.

Li, M., Li, B., Cao, G., Tian, J., 2017. Monolithic MAPbI ${ }_{3}$ films for high-efficiency solar cells via coordination and a heat assisted process. J. Mater. Chem. A 5 (40), 21313-21319.

Liu, M., Jia, M., Pan, H., Li, L., Cang, M., Ren, H., Argoul, F., Zhang, S., Xu, J., 2014. Instrument response standard in thime-resolved fluorescence spectroscopy at visible wavelength: quenched fluorescein sodium. Appl. Spectrosc. 68 (5), 577-583.

Luo, Q., Zhang, C., Deng, X., Zhu, H., Li, Z., Wang, Z., Chen, X., Huang, S., 2017. Plasmonic effects of metallic nanoparticles on enhancing performance of perovskite solar cells. ACS Appl. Mater. Interfaces 9 (40), 34821-34832.

Luo, Q., Deng, X., Zhang, C., Yu, M., Zhou, X., Wang, Z., Chen, X., Huang, S., 2018. Sol. Energy 169, 128-135.

Miao, H., Chen, B., Yongbo, Y., Yang, B., Jinsong, H., 2016. Stabilized wide bandgap $\mathrm{MAPbBr}_{\mathrm{x}} \mathrm{I}_{3} \mathrm{x}$ perovskite by enhanced grain size and improved crystallinity. Adv. Sci. 3 (6), 1500301.

Nam Joong, J., Jun Hong, N., Young Chan, K., Woon Seok, Y., Seungchan, R., Il, S.S.,
2014. Solvent engineering for high-performance inorganic-organic hybrid perovskite solar cells. Nat. Mater. 13 (9), 897-903.

Nam Joong, J., Jun Hong, N., Woon Seok, Y., Young Chan, K., Seungchan, R., Jangwon, S., Il, S.S., 2015. Compositional engineering of perovskite materials for high-performance solar cells. Nature 517 (7535), 476-480.

Noel, N.K., Stranks, S.D., Abate, A., Wehrenfennig, C., Guarnera, S., Haghighirad, A.A., Sadhanala, A., Eperon, G.E., Pathak, S.K., Johnston, M.B., 2014. Lead-free organic-inorganic tin halide perovskites for photovoltaic applications. Eng. Environ. Sci. 7 (9), 3061-3068.

Pellet, N., Gao, P., Gregori, G., Yang, T.Y., Nazeeruddin, M.K., Maier, J., Grätzel, M., 2014. Mixed-organic-cation perovskite photovoltaics for enhanced solar-light harvesting \& dagger. Angew. Chem. 126 (12), 3215-3221.

Po-Wei, L., Chien-Yi, L., Chu-Chen, C., Fan, Z., Williams, S.T., Xu-Kai, X., Jiangjen, L., Alex K-Y, J., 2014. Additive enhanced crystallization of solution-processed perovskite for highly efficient planar-heterojunction solar cells. Adv. Mater. 26 (22), 3748-3754.

Saliba, M., Zhang, W., Burlakov, V.M., Stranks, S.D., Sun, Y., Ball, J.M., Johnston, M.B., Goriely, A., Wiesner, U., Snaith, H.J., 2015. Plasmonic-induced photon recycling in metal halide perovskite solar cells. Adv. Funct. Mater. 25 (31), 5038-5046.

Saliba, M., Matsui, T., Domanski, K., Seo, J.Y., Ummadisingu, A., Zakeeruddin, S.M., Correa-Baena, J.P., Tress, W.R., Abate, A., Hagfeldt, A., Grätzel, M., 2016a. Incorporation of rubidium cations into perovskite solar cells improves photovoltaic performance. Science 354 (6309), 206-209.

Saliba, M., Orlandi, S., Matsui, T., Aghazada, S., Cavazzini, M., Correabaena, J.P., Gao, P., Scopelliti, R., Mosconi, E., Dahmen, K.H., 2016b. A molecularly engineered holetransporting material for efficient perovskite solar cells. Nat. Energy 1 (2), 15017.

Shi, J.H., Li, Z.Q., Zhang, D.W., Liu, Q.Q., Sun, Z.Z., Huang, S.M., 2015. Fabrication of Cu (In, Ga) $\mathrm{Se}_{2}$ thin films by sputtering from a single quaternary chalcogenide target. Prog. Photovoltaics 19 (2), 160-164.

Tavakoli, M.M., Giordano, F., Zakeeruddin, S.M., Grätzel, M., 2018. Mesoscopic oxide double layer as electron specific contact for highly efficient and UV stable perovskite photovoltaics. Nano Lett. 18 (4), 2428-2434.

Turren-Cruz, S.-H., Hagfeldt, A., Saliba, M., 2018. Methylammonium-free, high-performance, and stable perovskite solar cells on a planar architecture. Science 362 (6413), $449-453$.

Wang, Y., Liu, S., Zeng, Q., Wang, R., Qin, W., Cao, H., Yang, L., Li, L., Yin, S., Zhang, F., 2018a. Enhanced performance and stability of inverted planar perovskite solar cells by incorporating 1, 6-diaminohexane dihydrochloride additive. Sol. Energy Mater. Sol. Cells 188, 140-148.

Wang, M., Zang, Z., Yang, B., Hu, X., Sun, K., Sun, L., 2018b. Performance improvement of perovskite solar cells through enhanced hole extraction: the role of iodide concentration gradient. Sol. Energy Mater. Sol. Cells 185, 117-123.

Wintzheimer, S., Granath, T., Oppmann, M., Kister, T., Thai, T., Kraus, T., Vogel, N., Mandel, K., 2018. Supraparticles: functionality from uniform structural motifs. ACS Nano 12 (6), 5093-5120.

Yuan, Z., Wu, Z., Bai, S., Xia, Z., Xu, W., Song, T., Wu, H., Xu, L., Si, J., Jin, Y., 2015. Perovskite solar cells: hot-electron injection in a sandwiched $\mathrm{TiO}_{\mathrm{x}}-\mathrm{Au}-\mathrm{TiO}_{\mathrm{x}}$ structure for high-performance planar perovskite solar cells. Adv. Energy Mater. 5 (10), 10.

Zeng, X., Zhou, T., Leng, C., Zang, Z., Wang, M., Hu, W., Tang, X., Lu, S., Fang, L., Zhou, M., 2017. Performance improvement of perovskite solar cells by employing a CdSe quantum dot/PCBM composite as an electron transport layer. J. Mater. Chem. A 5, 17499-17505.

Zhang, C., Luo, Y., Chen, X., Chen, Y., Sun, Z., Huang, S., 2016. Effective improvement of the photovoltaic performance of carbon-based perovskite solar cells by additional solvents. Nano-Micro Lett. 8 (4), 347-357.

Zhang, C., Luo, Q., Deng, X., Zheng, J., Ou-Yang, W., Chen, X., Huang, S., 2017a. Enhanced efficiency and stability of carbon based perovskite solar cells using terephthalic acid additive. Electrochim. Acta 258 (20), 1262-1272.

Zhang, C., Luo, Q., Deng, X., Zheng, J., Wei, O.Y., Chen, X., Huang, S., 2017b. Enhanced efficiency and stability of carbon based perovskite solar cells using terephthalic acid additive. Electrochim. Acta 258 (20), 1262-1272.

Zhang, H., Nazeeruddin, M.K., Choy, W.C., 2019. Perovskite Photovoltaics: The significant role of ligands in film formation, Passivation, and Stability. Adv. Mater. 31 (8), 1805702.

Zhang, W., Saliba, M., Stranks, S.D., Sun, Y., Shi, X., Wiesner, U., Snaith, H.J., 2013. Enhancement of perovskite-based solar cells employing core-shell metal nanoparticles. Nano Lett. 13 (9), 4505-4510.

Zhang, J., Sun, L., Yin, J., Su, H., Chunsheng Liao, A., Yan, C., 2002,. Control of ZnO morphology via a simple solution route. Chem. Mat. 14 (10), 4172-4177.

Zhang, L., Xu, L., Li, Q., Su, J., Li, J., 2018. Double-edged sword effects of cation rotation and additive passivation on perovskite solar cell performance: an ab initio investigation. Sol. Energy Mater. Sol. Cells 186, 349-355.

Zhao, L., Luo, D., Wu, J., Hu, Q., Zhang, W., Chen, K., Liu, T., Liu, Y., Zhang, Y., Liu, F., 2016. High-performance inverted planar heterojunction perovskite solar cells based on lead acetate precursor with efficiency exceeding 18\%. Adv. Funct. Mater. 26 (20), 3508-3514.

Zhou, H., Chen, Q., Li, G., Luo, S., Song, T.B., Duan, H.S., Hong, Z., You, J., Liu, Y., Yang, Y., 2014. Photovoltaics. Interface engineering of highly efficient perovskite solar cells. Science 345 (6196), 542-546.

Zhou, T., Wang, M., Zang, Z., Tang, X., Fang, L., 2019. Two-dimensional lead-free hybrid halide perovskite using superatom anions with tunable electronic properties. Sol. Energy Mater. Sol. Cells 191, 33-38.

Zhu, H., Hüpkes, J., Bunte, E., Owen, J., Huang, S.M., 2011. Novel etching method on high rate $\mathrm{ZnO}$ : $\mathrm{Al}$ thin films reactively sputtered from dual tube metallic targets for silicon-based solar cells. Sol. Energy Mater. Sol. Cells 95 (3), 964-968.

Zhu, G., Lin, T., Lü, X., Zhao, W., Yang, C., Wang, Z., Yin, H., Liu, Z., Huang, F., Lin, J., 2013. Black brookite titania with high solar absorption and excellent photocatalytic performance. J. Mater. Chem. A 1 (34), 9650-9653. 